\title{
Corporal Punishment of Children in Iranian Law and International Instruments
}

\author{
Ahmad Reza Behniafar ${ }^{1} \&$ Mahmood Poyan $^{2}$ \\ ${ }^{1}$ Department of Islamic Thoughts, Damghan Branch, Islamic Azad University,Damghan, Iran \\ 2 Department of Law, Damghan Branch, Islamic Azad University, Damghan, Iran \\ Correspondence: Ahmad Reza Behniafar, Department of Islamic Thoughts, Damghan Branch, Islamic Azad \\ University,Damghan, Iran. E-mail: behniafar@yahoo.com
}

\author{
Received: March 9, 2016 Accepted: April 5, 2016 Online Published: April 27, 2016 \\ doi:10.5539/jpl.v9n3p16 URL: http://dx.doi.org/10.5539/jpl.v9n3p16
}

\begin{abstract}
Corporal punishment of children in their education are important issues that historically have been accepted and Yankvhsh Unfortunately in today's society has neglected the rights of children and adults of these rights by violated. Islamic jurisprudence is recommended to right what ways? As well as laws have been codified in law what is? In the verses of Quran and Hadith from the infallible Imams come from (PBUH) emphasizes the reverence, love, forgiveness, compassion and Rfq and productive than children. On Islamic law, as is early in the punishment of child esteem and under certain conditions as a measure to maintain the system for training and behavior modification, family and children, voided, and to protect the interests, sanctions such as liability and responsibility, provided is. In this regard, in particular understanding of Islam and Shiite jurisprudence that laws in our country is the source and the directive could be an important step for appropriate legislation B for children. The law tries years of punishment and corporal punishment of children to prevent and eliminate this phenomenon in human society and in recent years a comprehensive international instrument to assert the rights of children and the prohibition of corporal punishment for exercising their raised have. Thus, at the outset, and seemingly contradictory approaches is formed. Therefore, in this study, explain and evaluate the real subject of two approaches have been tried according to the interests, rights, education, interests and protect the interests of children, the ways to close the two approaches together will be offered.
\end{abstract}

Keywords: children, physical punishment, discipline, Jurisprudence, rights, responsibility

\section{Introduction}

Education, the main goal is that all religions are true aspects of human existence and its light takes shape. Islam in order to achieve this goal, methods and different parenting styles, the encouragement and preached to threat and punishment, is provided. The core of the family as the foundation of society and humanity can be trained in the proper implementation of moral and spiritual education of children, which is of particular importance, play a significant role. In other words, the family of the original founders of personality growth and prosperity of children.

Corporal punishment of children is one of the educational methods in specific cases and situations and circumstances in order to correct their behavior will apply. But due to improper use, often does not give desired results, and perhaps may appear to be the agent of destruction, to the extent that some education professionals, it has revealed aspects of reform and of punishment are prohibited. It will overlook the causes of violence against children.

We want the punishment to correct unacceptable behavior and prevent the commission of this child, to apply them in terms of Islamic jurisprudence and law study. Islam views in this regard can be accurately addition to selecting a correct and complete education process in line with the upbringing of children, sometimes important in enacting appropriate legislation in relation to children.

In this article we try to find ways to enact strict laws and provide training and providing appropriate solutions to prevent abuse and child abuse are a step in the hope of appeasing the child's pain relief but cry defense no.

Statement of the problem: 
In this article we will explain corporal punishment of children in law to approach law regarding corporal punishment of children and other mistreatment, examined the first Mmnvyyt corporal punishment in international and regional documents and then topic physical punishment of children in Iran deal

\subsection{Corporal Punishment of Children in International and Regional Documents}

Today, perhaps less subject to human rights to the attention of the international community is located. The scope of this issue is important enough in many international documents, to one or more aspects of issues related to human rights have been mentioned.

Among the various aspects of human rights, the rights of the child is important and special place. Although religious beliefs, culture, customs and rituals may be different to some areas and aspects of human rights in domestic and international arenas accepted or not be unanimous, but the Rights of the Child of those rights human conflict and confrontation is the least exposed.

Today the Rights of the Child and the issues arising from it, a large part of the legal texts is dedicated to progressive countries and increasing attention to their cause, and dramatic changes on issues related to children's rights and respect for different aspects of it have been achieved is to prevent other people will not voluntarily enrolled their children or their education than their short and get to work.

After World War I all of your history full of human conflict and aggressive competition authority and ignoring the rights of the most vulnerable strata of human society, the child saw, went to some lengths to compensate for past mistakes. However, today's children to international compassion has not been completed, so that the actions of some NGOs or UNESCO, ILO decisions aside, before ratifying the CRC, unfortunately, are real , fundamental rights for children did not exist and that children benefit from it were legal, the same as that for other human society and should be recognized for access to rights of children were referred of human rights instruments in addition the documents were in addition to the mandatory aspects were not emphasized on child-specific needs and requirements.

In recent decades, many documents and meeting children's rights as human rights or independently investigated also for the child's best interests, duties and obligations of states and families have put their shoulders. The documents on children's rights to protection from all forms of physical and psychological violence and harassment inflicted injury or a ban on punishment and corporal punishment against children and women is underlined But since the documents separately, over a period 60 years without paying particular attention to the basic needs of the child have rights that are granted to children are not fully comprehensive. In addition, the conditions that they impose must not be including children, while the condition of children is different from adults and children should have their own rules and regulations. Some of these regional and international instruments that protect the rights and the prohibition of corporal punishment on a child can be harvested from them are:

1) Universal Declaration of children

2) Convention on the Rights of the Child

3) United Nations Universal Declaration of Human Rights

4) The International Covenant on Economic, Social and Cultural

5) International Covenant on Civil and Political Rights

6) Convention against torture and other degrading treatment or punishment cruel, inhuman and degrading

7) The European Convention on Human Rights

8) American Convention on Human Rights

9) The African Charter on the Rights and Welfare of the Child

10) European Social Charter

The more threads are trying to ban corporal punishment in international and regional documents shall be discussed.

1.1.1 Prohibition of Corporal Punishment in International Instruments on the Rights of the Child

Bans physical punishment of children is expressed in different legal documents. Documents specifically related to the rights of the child are:

1. Declaration on the Rights of the Child, 2 the Convention on the Rights of the Child. Declaration of the Rights of the Child for the first time, discussion of corporal punishment in this Declaration we welcome. 


\subsubsection{Declaration on the Rights of the Child}

Because of the importance of child rights that the United Nations since its establishment were taken into account. The UN Commission on Social Development venture to develop a plan as a draft Declaration of the Rights of the Child, in 1959, a provisional draft of the Universal Declaration of Human Rights Commission on the Rights of the Child by the United Nations Economic and Social Council and the General Assembly the twentieth meeting in November 1959 a resolution was adopted unanimously.

The Declaration, the first universal children's independent legal document and contains 10 principles which, to education and special protection of children and the prohibition of all forms of discrimination against children is mentioned.

The introduction of this reads as follows:

"Considering that members of the United Nations Charter, faith in fundamental human rights and reaffirms the dignity and worth of human beings and to promote social development have been determined to improve living conditions in greater freedom.

Considering that the United Nations Universal Declaration of Human Rights have insisted that all people regardless of race, color, sex, language, religion, political or other opinions, national or social origin, property, birth or other attributes, subject to the rights and freedoms prescribed in the universal Declaration of Human rights.

Whereas the physical growth and intellectual development of children due to lack of pre- and post-natal care and attention, including appropriate legal protection is needed.

Whereas the need for such care and special protection in the Geneva Declaration of the Rights of the Child and the Universal Declaration of Human Rights 1924 and the statute of the foundation of specialized international organizations related to the welfare of children is recognized.

The United Nations General Assembly:

The Declaration of Rights of the Child with the aim of childhood prosperous and the rights and freedoms will be trying to benefit himself and his society, officially brought to public awareness and the parents and women and men to as individuals, voluntary organizations, local authorities and governments want to recognize these rights and to ensure the respect of these rights through laws and other measures that are gradually pursued with the following principles of prudence. "

As was noted in the introduction to the Declaration, it is clear childhood spent with happiness and comfort, do not compatible with the physical and mental punishment.

Also of Articles 2, 4, 6, 9 and 10 of this Declaration, it can be inferred ban on corporal punishment of children. Article II of the Declaration provides that:

"The child shall enjoy special protection and facilities and means necessary to foster the physical, intellectual, moral or social him healthy and normal manner and in conditions of free and honorable, he is authorized by law or authorities. In legislation Therefore, the interests of children should have the highest priority. "

The fourth principle of the Declaration states:

"The child should benefit from social security. In order to nurture a healthy environment for children and mothers in need of special care and protection, including adequate attention before and after birth, benefit. The possibility of having child nutrition, housing, recreation and medical services are appropriate. "

The sixth principle of the Declaration says:

"Complete and balanced personality to nurture the child's need for love and understanding and should be under the care and supervision of their parents as much as possible and in any case in an atmosphere full of love in the security of the moral and material still be nurtured. Young children, except in exceptional circumstances, be separated from the mother. Community and social status are required as compared to children without a family and pay particular attention to underprivileged children.

Government cash assistance and other facilities to ensure the maintenance of children of large families is recommended. "

The ninth principle of the Declaration states:

"The child must resist any neglect, oppression, cruelty and exploitation can be protected. The child should be in any way by the exchange. The child should enter before reaching the minimum age for employment and should 
by no means be possible or allowed employment and should by no means be possible or allow the employment of children in work to the health and damage his Yaamvzsh the potential to impair or physical growth, intellectual or moral is he. "

As well as Article I says:

"Keep the child against any attitudes and behavior that promote racial discrimination, religious, etc. makes possible, be supported. Children should Prtfahm spirit, forgiveness, believe in friendship between peoples, peace and universal brotherhood and in full consciousness that the abilities and talents should be devoted to the service of his fellow men, and nurtured ".

What are the principles in the Declaration of the Rights of the Child harvest, the special protection of children against hardships and abuse behaviors that physical punishment is one of those cases does not fit and the spirit of the principles of such a punishment.

1959 United Nations Declaration on the Rights of the Child, executive commitment to world governments and not a legal value to the United Nations General Assembly resolutions. On the other hand, the world witnessed a clear violation of child rights, hence the need to develop an international treaty that must be approved and accepted by various nations, was clearly felt. Thus, the Convention on the Rights of the Child 1989 a resolution was adopted by the General Assembly.

\subsubsection{Convention on the Rights of the Child}

Among the various instruments of international law to ban corporal punishment of children and their legal protection have been identified, the Convention on the Rights of the Child about to such an interpretation.

This Convention, of which the most important international instrument for the comprehensive protection of children and children's interests, on the twentieth of November 1989 by the United Nations General Assembly unanimously passed that consists of an introduction and 54 articles. Article 41 relates to the rights of children and 13 of them related to the performance in each country. So far, 191 countries out of 193 countries have joined it and only the United States and Somalia had not been accepted to join.

However, it can be said provisions of the CRC and its related parts of the country was accepted as customary international rule accordingly, and even for non-member countries shall be observed; what it is that Convention by the Assembly UN general accepted the consensus opinion, and has been adopted by a wide majority. In addition to that, the United States and Somalia have signed this Knvanyvn. Therefore, CRC as international law applicable in most universally accepted. The Convention, as a legally binding instrument, while a broad and comprehensive protection of children as the most important human capital of the country, was able to consolidate and clarity of role and responsibility as the ruling class and the ruling family and the government has a special responsibility towards children; and for this reason, are required to determine the status of the Convention in their country and its impact on domestic law and take measures to achieve the objectives of the Convention considered. On the other hand, it is necessary that the duties and obligations to supervise children in families; and in case of failure to perform the duties of the family and their inability to act and by different methods, duty of care and protection of children they are responsible for.

The main purpose of this Convention, a better life for their children and trying to harmonious and balanced development of the fundamental aspects of physical, mental, emotional, psychological and social development, and to achieve this goal, jihad-driven growth, survival, protection and participation is considered.

The characteristics of CRC, including the scope and extent of it, which means that its principles and provisions, all the world's children, regardless of gender, race, ethnic certain conditions, nationality, religion and so on under the covers; the main principles of hierarchy and no it does not take precedence over other principles; and the implementation of its principles is emphasized as a necessity.

Which is one of the principles underlying principles and under the Convention is to respect the principle of the best interests of children and the right to life, survival and growth of the child. According to this principle, governments and families should consider the child's interests. Compliance with the "best interests of the children" is just the institutions and will not be public, but also private institutions are also included. Convention respecting the principle of the best interests of the child as a guiding principle considered, and affirms interest of the child should be a priority in any action; clearly states that actions should be such that the most basic parenting child's best interests are preserved. in addition, all states Parties to adopt legislative, administrative, social and educational measures to protect children and protect their interests and to adapt their national legislation with the provisions of the Convention requires that material. 
Therefore, one of the most important principles of the Convention, it emphasizes the duty and obligation of members to protect children against physical abuse their bodies. Committee on the Rights of the Child, which monitors implementation of the Convention, states the provisions of the CRC - and Dygr the spirit of the Convention - with corporal punishment is inconsistent and contradictory. The official report of the committee announces its seventh session in November 1994:

"In the framework of the mandate of the Committee, the Committee on the Rights of the Child and to pay particular attention to the physical abuse he has, in this regard, with the same mentality expressed concern that corporal punishment, is not compatible with the Convention, and in most cases offer that the regulations in the country, be revised and amended, as well as education and awareness programs to prevent abuse and child abuse and corporal punishment of children be developed."

Thus, reports Child Rights Committee affirmed that corporal punishment is incompatible with a set of Convention on the Rights of the Child; and such a penalty diagnosis of child abuse; and support the idea that the prohibition of corporal punishment of children as part of It is essential to recognize the treaty.

\subsubsection{Ban on Corporal Punishment in International Documents on Human Rights}

Among other Allmlly documents that can be inferred from the prohibition of corporal punishment in law, including in this document, the United Nations Universal Declaration of Human Rights, the International Covenant on Economic, Social and Cultural Rights, the International Covenant civil and political rights and the Convention against torture.

In this context, the prohibition of corporal punishment of children in these documents will be examined.

\subsubsection{The United Nations Universal Declaration of Human Rights}

Universal Declaration of Human Rights, the most important international instrument world and the first achievement of the UN Commission on Human Rights in the framework of Article 68 of the UN Charter by the UN Economic and Social Council is, and I'm in Paris in December 1948 attended by representatives all 50 countries at the time, without any dissenting votes in the UN general Assembly approved. This Declaration was the direct result of World War II and the first rights that all human beings are entitled, for the world is expressed. Declaration consists of 30 articles which outlines the views of the United Nations on human rights. The provisions of this Declaration of fundamental rights civil, cultural, economic, political and social that all human beings in every country should have it has identified.

Iran is one of the countries in the years before the revolution in the Universal Declaration of Human Rights in the UN General Assembly in 1948 and has participated and voted for it after the victory of the revolution on the Islamic Republic of Iran has signed to endorse .

Universal Declaration of Human Rights, although in the form of a declaration is approved, but due to its repetition in future international legal documents, and stressing the importance of human rights in all resolutions issued by the UN General Assembly and the Commission legal, it becomes clear that the provisions of customary international law aspects, respectively. In this regard, in the case Fylartga Rights Commission in 1980 explicitly states that the declaration be considered as a source of rules of customary international law.

About the ban on corporal punishment of children, although not expressly stated in this announcement that expresses the substance of such a right had children, but the ban can be harvested from some of the material because, this Declaration to protect the rights all human persons, and children are part of the set.

Because of this claim, the introduction of the Declaration, which explicitly states:

"Whereas recognition of the inherent dignity of all members of the human family and Hysyt and the equal and inalienable rights are the foundation of freedom, justice and peace in the world up.

Because of the lack of recognition leads to acts of violence and contempt for human rights have led humanity to the spirit of rebellion and advent of a world in which human beings express opinion, Zadv of fear and poverty, have graduated as the highest human aspirations declared Are.

Because basically human rights should be protected by law enforcement as a last resort, to rebellion against tyranny and human to not have pressure.

Since it is essential to promote the development of friendly relations between nations.

Since the United Nations, their faith in fundamental human rights and the dignity and worth of the human person in the charter rights of men and women Vtsavy again, and have declared their determination to contribute to social progress and better living conditions in a freer environment create. 
Since I have been a member of universal respect for and observance of human rights committed and fundamental freedoms in cooperation with the United Nations meet.

Whereas a common understanding of these rights and freedoms for the full realization of this pledge, the greatest importance, the General Assembly of the Universal Declaration of Human Rights as a key common to all people and nations, declares and all the pillars of the community, this Declaration constantly in mind, and that efforts by education, develop respect for these rights and freedoms and by progressive measures, national and international, their universal and effective recognition and observance, both among its member nations and What among the countries that are in their territory be delivered."

\subsubsection{The International Covenant on Economic, Social and Cultural}

Since the Universal Declaration of Human Rights, the Convention is not binding - though as the international norm has been accepted all over the world - rights enshrined in the International Covenant on it (Covenant on Civil and Political Rights and the Covenant on Economic, social and cultural) has become binding, and a contract, and the government is obliged to implement its provisions. The International Covenant on Economic, Social and Cultural Rights adopted by the Sixteenth December 1966 the UN General Assembly in 1354, which Iran has ratified the Covenant in its legal authorities under article 9 of the Civil Code now its provisions in domestic laws are ruling .

In this global legally binding instrument on the prohibition of corporal punishment are not discussed explicitly, but can be obtained from this. Article 12 of the Convention states:

"1. States Parties to the Convention on the right of everyone to the enjoyment of the highest policy to recognize the physical and spiritual.

2. States Parties to the present Covenant measures to ensure the full restoration will include the right to take necessary measures to provide the following duties:

A) reduce the amount of dead born children - child mortality and the development of child health.

B) improve the health of all aspects of environmental and industrial hygiene.

C) prevention and treatment of epidemic diseases - Native - Professional and other diseases, as well as fight against these diseases.

D) the creation of appropriate conditions for the provision of medical advice and medical assistance to the public in the event of illness."

In the first paragraph of the said article shows that everyone has the right to benefit from the best physical and mental health as well. And in the second paragraph of this Article shall take the necessary measures to achieve this right is stated. And in the "a" of member states are obliged to take measures for the development and growth of children's health and reducing mortality them to do.

The third paragraph of Article I provides that the Convention shall:

"Special measures such proportion or other conditions without supplementary support and assistance to all children and young people is needed. Children and young people have the operation (exploitation) be protected from economic and social. If their employment is detrimental to their health or morality and endanger their life or hinder their normal development. However, such employment is punishable by law. Governments also must be of age (hire for children) decide to hire less than that (age) do not. Recruitment of child labor is prohibited by law and can be punished."

It is true that the recruitment of children as workers, is punished, but the reason for the ban corporal punishment was considered to be the source so that one of the reasons for the prohibition of recruitment of children as workers, is that such practical harm their physical and mental health; in other words, physical integrity of children this will happen Khtrmy. Therefore, to maintain their physical health such action is prohibited and permitted. However, a fortiori, punishment, corporal punishment is in direct conflict with the child's physical health, the practice is prohibited and is punishable and follow-up.

In the first paragraph of Article 13 also says:

"The government Zvayn of the Covenant, the right of every person to enjoy the benefits of education to recognize. They agree that education shall be directed to the full development of personality and dignity (dignity) of the human person and respect for human rights and fundamental freedoms and strengthen the lead. They also accept that education can participate in a community Zadv active and influential people in the spirit of understanding, tolerance and friendship among all nations and ethnic groups, ethnic or religious superior of 
United Nations activities for the realization of peace binding. "

What is obtained from this material, in the first place children's need for support and attention in the society and the government should take steps towards the development of their physical and mental health, in addition to the fact that according to this document, child labor as has been forbidden action is, and the reason for this is that such an operation to growth, development and health of children hurt. However, how is it possible physical abuse that directly targets children's physical health, be allowed?

Committee on Economic, Social and Cultural general explanation of his number 14 is:

Acquiring right of children to health growth, to boost children's health and that such a thing is done, need to accept painful measures to eliminate traditional practices that affect children's health. Also, should the children be given the opportunity to enjoy a decent life and satisfactory.

Super committee to eliminate all corporal punishment of children in schools, in general describes his No. 13 has stated:

"In terms of the committee, corporal punishment, contrary to and inconsistent with the fundamental guiding principle in the premises of the Universal Declaration of Human Rights and the rights that are the two Covenants. A State Party shall adopt measures to ensure discipline with the International Covenant on Economic, Social and Cultural incompatible, in any public or private educational institution not happen. The Committee of measures adopted by some member states, that actively encourages schools to make positive non-violent methods to discipline introduced in school are welcome."

\subsubsection{International Covenant on Civil and Political Rights}

XVI International Covenant on civil and political rights on December 1966 has been approved by the United Nations General Assembly and Plenipotentiary representative of the Iranian government signed in New York became the fourth April 1968 after approval by the National Council at a meeting on Tuesday, November twenty-third 1351 at a meeting on Wednesday the Senate approved the seventeenth of May 1354 Hijri.

Some of these binding international document can be in the form of implicit prohibition of corporal punishment of children achieved. Article 7 of the Covenant provides that:

"No one shall be subjected to torture or to cruel and inhuman treatment and cruel or degrading treatment," he says.

As stated, the term "no one" is in such documents, including children, as human being as well.

Human Rights Committee has stated that two public comment on this matter: first in 1982, General Comment No. 7, and the second general comment number 20 in 1992, which replaced general explanation was number 7 , that it and will reflect more widespread. The Committee urges the general explanation:

"The purpose of the provisions contained in Article 7, the protection of the dignity of the individual, and his physical and psychological integrity is protected. The task of government members who, through legislative measures or other measures, to protect any person against the acts prohibited in Article 7, pay, whether the perpetrator is an official of the prohibited acts, or outside in his official capacity or as private ... Read Article 7 does not allow no limits. The Committee also emphasized this aspect even in emergency situations to the public ... no violation of article 7 is allowed and its provisions must remain in force. The Committee also notes that violation of article 7 for any reason, no justification or mitigating circumstances, including command of a senior officer or a public authority can not be appealed. "

"The Committee also is required to provide a list of prohibited acts or clear distinctions between different forms of punishment or behavior make a difference depends on the nature, purpose and severity is done."

The Human Rights Committee, notes the prohibition of torture and cruel chastisement or cruel, inhuman and degrading treatment including corporal punishment is also:

"Prohibition contained in Article 7 only to acts that cause physical pain, they are not related, but, actions which cause mental suffering of victims are also included. Furthermore, I think the committee should include a ban on corporal punishment, including severe punishment 'which as a punishment, as a result of a crime or as an act of discipline, be ordered. In this respect, it is impor- tant to emphasize Article 7, especially of children, students in educational institutions and patients in health institutions it supports ".

Use this in conjunction with Article 37 of the Convention on the Rights of the Child, to the conclusion that Article 7 also applies to children, and this prohibition applies to all children, wherever they may be, will be. Such an interpretation with regard to Article 24 of the International Covenant on Civil and Political Rights is enhanced. 
This article dedicated to the interests of the children, says:

"Every child, without any discrimination of race, color, sex, language, religion, national or social origin, property or birth, that due to the development of the young state, the right to such measures of protection - family support, community and government be."

Carefully International Covenant on Civil and Political Rights Article 24 can be seen, the vulnerability of children is targeted and accordingly, they will include special protection, the prohibition of corporal punishment is among them.

In addition to the first paragraph of article 9 of the Covenant on Civil and Political Rights bans physical punishment of children in some states. Paragraph I of this article states:

"Everyone has the right to liberty and security of person. No one shall be arbitrarily (unlicensed) arrest or detention (prison) said. No one shall be deprived of his liberty except on such grounds and in accordance with such procedure as are established by law".

As stated, the term "security of person" mentioned in this article, is opposed to and in conflict with corporal punishment. In this regard, although the Human Rights Committee specifically corporal punishment of children is not addressed under Article 9, as in Article 7 and 24 is the same. But the committee has released its Final Comments, family and domestic violence against women in particular, under Article 9 declares.

It can be said that both domestic violence and corporal punishment in most cases, are included beatings and corporal punishment is not compatible with physical security.

\subsubsection{Convention against Torture and Other Degrading Treatment or Cruel, Inhuman or Degrading}

Treatment or Punishment Convention Against Torture and other cruel, inhuman or degrading, on the tenth of December 1984 during a preamble and 33 articles (in 3 parts) was approved by the United Nations General Assembly and on the twenty-sixth of June 1987 in accordance with Article 27 Convention's entry into force.

This Convention shall be binding among the documents is not limited to particular classes and groups, and contains the most extensive and scope of inclusion of all human beings to be protected so that the resolution dated 32/62 th December 1977 and the provisions of this Convention becomes apparent, Declaration on the protection of all persons against torture or other cruel, inhuman and degrading (1975) of the underlying instrument is present.

Convention that attempted to define a comprehensive and acceptable to the various international judicial bodies of tortured and executive mechanism - and the more serious and more effective surveillance to combat the torture and other of the importance of inhuman treatment inked enjoys a special status among other human rights instruments and has 147 members, and over 51 states in the application of Articles 21 and 22 of the committee's competence have been identified, a number of governments have accepted the present Convention with the reservation of the major provisions of Article 20, which states about the competence of the committee against torture to investigate and verify the existence of torture in a State Party and Article 30 on the settlement of disputes referred to arbitration and the international Court of Justice.

The Islamic Republic of Iran has so far not joined the Convention. Text of the Convention on dated 05.01.1382 for the project signed legislation to a significant number of Muslim MPs and over a single article and without reservation to the Islamic Consultative Assembly to pass, but the Guardian Council in the meeting dated 15/5 / government of the Islamic Republic of Iran's 1382 accession to the Convention's proposals in this regard that the financial burden is for the project, contrary to Article 75 of the constitution recognized and does not demonstrate it.

The preamble of the Convention, the General Assembly, Recalling the Declaration on the Protection of All Persons under treatment or punishment torture and other cruel, inhuman and degrading (1975) and Resolution $32 / 62$ (1977) and 38/119 (1983) and the referring to the principles of the UN Charter and human rights inherent dignity of the universal declaration of Human rights prohibit torture and the international Covenant on civil and political rights, has stated that the present Convention to tend to more effective the struggle against torture and other punishment or treatment cruel, inhuman and degrading passed with the consent of governments.

Treatment or Punishment Convention Against Torture and other cruel, inhuman, degrading, another international mandatory instruments that can be used to ban corporal punishment. The Convention also states that support for all members of the human family included. Therefore, each child regardless of whether the law or its own article on the prohibition of torture and other inhuman and cruel behavior have, under the provisions of this Convention are addressed. 
It can be said: Integrity Convention on the prohibition of corporal punishment implies simply because the punishment and corporal punishment is a form of abuse that is physical integrity of children, and the punishment stage sometimes seems that in addition to the adverse effects physical, mental aberrations as well. Thus, corporal punishment could be in the range of other abuses, such as torture and cruel, inhuman or degrading treatment as well. Every so often, some of these abuses like behavior in other ways other than corporal punishment is degrading to enter the baby. In other words, can not say just punishment and corporal punishment is an act, but also fits on a collection of other titles; and in logical terms, the ratio between public and private is absolute.

Article 2, the Convention provides that:

"1. Each State Party to this Convention, shall take the necessary measures and effective legislative, administrative, judicial or other measures to prevent acts of torture in any territory under its jurisdiction to take action.

2. No exceptional circumstances countries, such as war or threat of war, internal political instability or any other emergency situation, is not licensed and administered OF TORTURE.

3. An order from a superior officer (Government) or a public authority can not justify the practice is fragile. "

\subsubsection{Ban on Corporal Punishment of Children in Regional Instruments on Human Rights}

There are many regional instruments which can be used to ban corporal punishment of children, including documents of the European Convention on Human Rights, the American Convention on Human Rights, the African Charter on the Rights and Welfare of the Child and the European Social Charter. In addition, a ban on corporal punishment of children in the legal trace.

\subsubsection{The European Convention on Human Rights}

The European Convention on Human Rights and is sometimes referred briefly to the European Convention, the "European Convention for the Protection of Human Rights and Fundamental Freedoms" is.

The Council of Europe Convention, including written documents. The regional document immediately after World War II by the member states of the Council of Europe in 1949 with the aim of cultural development, political and social life of Europe and promote human rights, democracy and the rule of law was developed in Europe.

The preparation of this document and begin to work fast and the Council of Europe, in order to respond and react in the face of obvious and serious violations of human rights in Europe during the World War II had taken place. Finally, after many attempts that were in line with the development of this document, referred to in the fourth Convention was adopted in November 1950 and entered into force in September 1953. This document binding as a treaty among the general treaties for the protection of human rights and fundamental freedoms and respect for the rights and freedoms covered several of its provisions binding by member states and with regard to the extent Since the implementation of this document are applicable document in the specified area including the regional instruments for the protection of human rights is considered possible.

One of the main advantages and distinctive features document recognized that the right of individual petition under the right of individuals and organizations are entitled to their disputes with government agencies violations of rights recognized in the Convention on the provide Strasbourg in particular they be addressed.

The regional document also bans physical punishment of children is well known. Article 3 of the Convention to debate ban on torture and other inhuman treatment or punishment, cruel deals. Court and European Commission of Human Rights, developed the content of the material and corporal punishment of children within the scope of this article is placed and has stated that corporal punishment is a violation of Article 3.

For example, in the case of Karen Warwick principal that he is smoking in the courtyard of the school. That's why corporal punishment, and he ran with a cane in his hand. After Karen's mother did not conclude the litigation in local courts, the European Court of Bshrtrh his fights Rights, the European Court considered this practice a violation of Article 3, and have such a humiliating and inhuman treatment be considered, and also asserted that this action, in addition to physical injury, psychological negative effects as well. Commission members believe that such injury is unacceptable for a boy; for the punishment of his parents or school teachers.

In the field of domestic violence against women, as a child because of his disobedience, the legs and hit his back, the court ruled that a violation of article 3 of the Convention, and said his children and other vulnerable persons, including governmental regarding the effective inhibition of these actions is at odds with personal dignity, are.

The European Court relating to the use of corporal punishments in schools in England, declared: 
"The mere fact that corporal punishment was used for a long time and most parents do agree it can not be used as a criterion to determine whether this punishment, degrading or not? It seems that the threat of corporal punishment under certain conditions and circumstances can shape the behavior is inhuman. "

The European Court of Human Rights, the legal procedure is that the physical punishment of children by parents, in addition to their corporal punishment in schools is a violation of article 3 of the European Convention, and the practice is prohibited, and even threatened to impose penalties under no circumstances can be considered physical inhuman treatment.

\subsubsection{The American Convention on Human Rights}

American Convention on Human Rights, including binding regional human rights treaties, which in November 1969 Twenty-Second Inter-American diplomatic conference in San Jose, Costa Rica, which was composed of American States was signed and ratified and entered into force in July 1978 Eighteenth .

The treaty of human life from the moment of conception (the birth of the baby or the pregnancy period) provides support. The preparation of this binding region could be a major step in the protection of human rights and fundamental freedoms in the American system of law.

Materials used in these regional document, which could be due to previous discussions concluded bans physical punishment of children. In paragraph 1 of Article 11 states:

"Everyone has the right to human dignity is respected."

As mentioned, corporal punishment is not compatible with human dignity being respected.

In addition, article 19, which refers to the protection of children, states that:

"Every little child has the right to the protections given to the condition and as a member of a small group of families, communities and countries, enjoy."

One should also support measures for children against abuse.

Article 5 of the Convention, as full legal bans physical punishment for children can be considered, says:

"1. Everyone has the right to moral dignity, respected and adhered to his mental or physical.

2. No one shall be subjected to torture, or behavior and cruel, inhuman and degrading placed. "

The juxtaposition of these materials can be easily reached to ban corporal punishment, although American Commission has emphasized that countries and member states should adopt a child Convention, and any violence that aimed at children the ban. Thus, the American Convention - the Convention on the Rights of the Child as well as corporal punishment is absolutely prohibited.

\subsection{Corporal Punishment of Children in Iran}

In our domestic law, which is based on Islamic law and Jurisprudence, to support the weak strata of society, appropriate legislation that followed the Civil Code and the Penal Code will be investigated.

\subsubsection{Civil Code}

As stated, some people like a ruler, father and teacher to train and discipline children and prevent the diversion and somewhat guilty that Islamic law has fixed those children, their physical Tbyh, but that does not mean beating and violence on children, no problem and no negative impact.

Fundamental principle of treatment is the role of Islam, encourage and invite the good things that unfortunately it is less emphasis on the families for various reasons. If the law provides for parents that do not exceed the limits specified, otherwise against the law and punish them, as well as other legal persons shall be sentenced to punishment because your parents have the right to punish children, but this right can not cite him more than the amount determined punish.

Parents and guardians legal actions for training and discipline or protecting the child should be treated at par and he performed solely for the purpose of treatment, as the first alternative 59 of the Penal Code in this case, has stressed.

Unfortunately, the limits set by the law, we are not presented clear and transparent explanation and definition of the boundaries determine the punishment, corporal punishment in law is not that people are allowed to what extent and allowed to punish a are, the only one brief reference, and other items or reckon, or at least not switched on.

In this respect the traditions of the infallible Imams (AS), which is clear about punishment of child and parent to 
child abuse resulting in red or blue if his body be condemned to the payment of blood money.

Finally, if the law does not reckon about punishment and explained, as well as open the way for abuse and Tzyyh Rights of the Child. Reform Act of 1173, in article 76 of the Civil Code states:

"If as a result of lack of care or moral decay parent of the child under his protection, physical health and moral education of the child is in danger, the court may at the request of the child or the guardian of his Aqrbay or at the request of the chairman of the jurisdiction, any to protect the child's decision, which it sees appropriate to adopt. "

Can be seen in this legal matter has been referred to the repeated assaults beyond the normal scope, while the obscure the standard minimum, which we hope as soon as possible legal see the remove vacuum executive Supports children too.

So, if a child's parents out of the ordinary and legal issues referred to punish your child act which consequently leads to physical injuries or defects and strengths of the child, according to the result of crimes committed as other criminals will be condemned to bear the legal punishment. Article 1179 of the Civil Code states that:

"Parents have the right to discipline your child, but your child can not invoke that right within the limits prescribed, punish."

\subsubsection{Penal Code}

Iranian criminal law for the first time in 1338 in the law establishing the court with jurisdiction to crimes offenders had children between 6 to 18 years was established, but after the Islamic Revolution legislator to juvenile delinquency and adult offenders subject to the general rules of contract special courts to cause did not show. Of course it did not last and eventually pursuant to Article 219 of the Code of Criminal Procedure of 1389, specialized branches of public courts were assigned to juvenile delinquency. The new Penal Code was enacted in 1392 specifically to consider children's offenses, it is considered what are huge advantages, especially in crimes according gradually accepted responsibility, separation of male and female, and punishment of body like a whip is removed.

According to article 49 of the Penal Code: "Children, if committing a crime, are exonerated from criminal responsibility and to train them; the court the responsibility of guardianship and juvenile institution for members is children."

Implementation certain punishment for pregnant or breastfeeding woman, or child is likely to incur losses, pursuant to Penal Code (Articles 91 and 92) is prohibited.

No criminal legislation of the Penal Code refers to the emotional and psychological abuse and lack of definition of this type of harassment, has to pass a series of laws that somehow protects children from abuse, emotional and psychological support that follows examines some of the they Prdarym:

According to Article 619 of the Penal Code (1375): Everyone in public places or thoroughfares, or disturb children or women protesting against the dignity and honor it or by the words and actions is to insult them, to imprisonment from two to six months and up to 74 lashes if convicted. An important point that should not insult would be a Hadd. So Chanchh committed, the punishment for accusing a child or a woman stipulated in Article 619 shall not apply.

The crime did not exist before the revolution in Iran's Penal Code. According to Article 139 of the Penal Code for accusing the term in the sense of attributing to someone else is adultery and sodomy. According to article 140 of the Penal Code, a Hadd to 80 lashes for accusing male or female. According to Article 146 of the Penal Code: (for accusing extent that in some cases lead for accusing adult, sane and is willing to mature too early and for accusing a Muslim and to be chaste. In case of qazf or early qazf one of these attributes is no fixed limit not).

Note Article 149 of the said Act states that: (a father or grandfather child is punished for accusing them. The father or grandfather punished according to Article 16 of this Law can be any punishment of imprisonment, fines and flogging to be much less). According to Article 147 of the Penal Code: (if a person other than his father and grandfather, the child is punished for accusing them up to 74 lashes).

Here mentioned in the legal protection of children and adolescents seems to be necessary:

- Article 1: All persons who have not attained the age of 18 years of all AH protection under the law benefit mentioned in this law.

- Article 2: Any harassment of children and adolescents who cause harm to their physical or mental, and moral and physical health or endanger their mental prohibited. 
- Article 3: Any purchase, sale, exploitation and use of children to commit offenses such as smuggling, banned and the offender, in addition to damages to six months to one year in prison or a fine of ten million rials will be sentenced to twenty million rials.

- Article 4: Whenever damage and harassment and physical and psychological torture of children and ignoring the health and physical and mental health and to prevent the government from education and commit to three months and one day up to six months in prison and tens of millions of Rials be sentenced.

- Article 5: general offenses of child abuse with no need for a private prosecution.

- Article 6: all persons and institutes and centers, which in a way are the responsibility of maintenance and child custody cases, child abuse Upon seeing much obliged to pursue and prosecute the perpetrators and make appropriate decisions to the competent authorities the case with. Violation of this rule leads to imprisonment for up to six months or a fine of up to five million rials will be.

- Article 7: training measures under Article 59 of the Penal Code and Article 1179 of the Civil Code Adopted 19.01.1314 07.09.1370 approved the inclusion of the law is no exception.

- Article 8: If the offenses covered by this law and other legal titles or other Qavnyn limit or severe punishment is prescribed for them, as the case may severely limit religious or punishment will be applied.

- Article 9 of the enactment of this law repealed all provisions contrary to it is acting. Mshml law on Article 9 at the open session of parliament on Monday passed on 09.25.1381 and on 10.11.1381 has been approved by the Guardian Council.

In the new Penal Code, adopted in 1392 in the tenth season as punishment and security measures and upbringing of children and adolescents is intended that all matter is this chapter about children. Article 95 of the Penal Code, adopted in 1392 as the last item in this chapter: criminal convictions of children and adolescents without works is criminal. The replacement of the Penal Code is intended for children. Even in cases where crimes according done by teenagers, stated that the court can postpone or suspend the sentence. 8 Articles in this section is about the children that some of these materials are joint and several note.

As can be seen, it seems that the Islamic Penal Code in relation to children and young people have a positive opinion on the bill, but the procedure is not anything about this, perhaps it is now time for juvenile crime in court certain of them dealt.

In addition, Article 88 of the Penal Code, adopted in 1392 says about the children and youth who commit crimes punished and their age at the time, 9 to 15 years the solar case, the court adopts one of the following decisions a) submission to the parents or the parents or legal guardian with a commitment to discipline and moral education of the child or youth in care.

Note-If the court deems expedient would be the case of the persons mentioned in the paragraph below and confirm their commitment to do things such as getting the result of the court's deadline:

1) Tell the child or youth to social workers or psychologists and other professionals working with them.

2) Send a child or youth in an educational institution and culture to education or vocational training.

3) Action for treatment or addiction child or youth under medical supervision.

4) Mshrt and prevention of harmful relationships with people to identify the child or youth court.

5) Preventing the movement of the child or youth in a certain neighborhood.

This is the first part of the child's parents be delivered to and taken from their commitment. But the second part contains the following:

B) submit to any other natural or legal persons that the court considers the requirement to carry out orders to the best interests of the child or youth referred to in paragraph (a) If the authority of parents, guardians or legal guardian of the child or youth or lack of compliance with the provisions of Article 1173 of the civil Code.

It has also been mentioned in the note submitted to qualified entities are required to pass to their children.

C) advice by judge

D) warning hints or signing a written declaration not to recidivism

E) kept in a juvenile institution from three months to one year in the case of crimes according grade one to five

90 Article 92 of the Islamic Penal Code on the Rights of the Child has emphasized even more important because the court could be due to reports of the condition of the child or adolescent and his behavior in a juvenile 
institution once their vote reconsider and reduce storage time up to one-third or maintenance to surrender the child or youth he turned to the parent or legal guardian. If that appeal court's decision to adopt a child or youth in a juvenile institution at least one-fifth of the storage period has passed.

The court's decision in this case is cans. This would prevent the use of conditional release and other legal allowances should not be considered to fulfill the conditions.

1) The consideration received in the traditions of the Infallible Imams (AS) and statements and fatwas of scholars and jurists as the "maximum maturity" and "maturity nikah 'is a reference, it can be concluded that the main criteria to reach maturity in boys, autoerotism and in girls, the sight of blood is menses and other symptoms of different ages and especially in our narrative, merely a sign of maturity, it is not relevant that path and development, not legislative.

2) Of course that typically determine the age of the girls, and boys wet dream and they see menstrual blood to reach sexual maturity, the Imam lawmakers is essential not as something Laytghyyr but as a criterion for diagnosis of physical and intellectual maturity in the realization of the conditions criminal responsibility of children is, because the realization of criminal responsibility, in addition to mature, complete perception (mental development) is also necessary. Thus, the age of responsibility, not relevant, but its path. Emirates distinction to maturity, so that medical tests to diagnose a person's maturity has been acting a certain age, usually between the ages of fulfillment of the conditions specified maturity and criminal responsibility (autoerotism and menstruation) occurs every though in different eras and nations certainly this is not the same age and this is why this age (9 to 15 lunar years) is not relevant in the realization of maturity and criminal responsibility.

3) Between Shiite jurisprudence and international legal system is different from the concept of childhood. International legal system in accordance with article one of the Convention on the Rights of the Child, a child means every human being below the age of eighteen years, but in the Shiite jurisprudence, the child who is said to still the age of maturity-girls nine lunar years and boys, are not Qmry- fifteen years. But Knfrasyvn Rights of the Child with regard to the following article one of the Convention on the Rights of the Child, in practice, has accepted the Shiite jurisprudence.

4) Punishment and corporal punishment is not defined in any international documents, but the legal procedure and legal doctrine, one can obtain examples and descriptions help to clarify the concept. However, in some of the examples of international instruments such as flogging, kicking, throwing, burning, slapping and corporal punishment and is against the law as a candidate is mentioned.

5) Reforms that corporal punishment of children in the Shiite jurisprudence is, as usual with the terms "discipline" and "punishment" are presented. "Discipline" means a person to invite to goodness and arrest evil and bad, and sometimes mean by punishment, punishment and listen financial loss can be achieved and a kind of punishment, retribution and punishment that to do for their offenses and sins that God has not determined the amount and size, is applied.

\section{Conclusion}

In order to answer the questions this study, discussion and conclusions are presented as follows:

1) the consideration of the traditions from the Infallible Imams (AS) and statements and fatwas of scholars and jurists that the "maximum maturity" and "nikah maturity" are mentioned, it can be concluded that the main criteria to achieve puberty in boys, autoerotism and the girls, seeing the blood menstruation and other symptoms, especially different ages in our narrative, not merely signs that path and relevance and maturity is something formative, not legislative.

2) determination of the age at which girls typically, blood menstruation see and boys wet dream and to reach sexual maturity, the legislation is necessary, but not as something unchangeable but also as a measure to fulfill the conditions of physical and intellectual maturity detection the criminal responsibility of children, as for the realization of criminal liability, in addition to mature, complete perception (mental development) is also necessary. Thus, the age of responsibility, not relevant, but its path. Statistical discrimination towards maturity, so that medical tests to diagnose action is maturing in a certain age, usually between the ages of maturity and fulfill the main conditions specified in the criminal liability (autoerotism and menstruation) the take each though in different eras and nations obviously, this is not the same age and that is why this age (9 to 15 lunar years) is not relevant in the realization of maturity and criminal responsibility.

3) the Shiite jurisprudence and international legal system in the case of children the difference. The international legal system in accordance with the Convention on the Rights of a Child, a child means every human being below the age of eighteen years, but in the Shiite jurisprudence, the child who is said to still the age of puberty - 
girls are not lunar years and boys, are not Qmry- fifteen years. But with regard to the Convention on the Rights of the Child following article is a "unless under the law applicable to the child, the age of puberty is determined to be" Knfvansyvn, in practice, has accepted the Shiite jurisprudence.

4) punishment and corporal punishment is not defined in any international documents, but the jurisprudence and legal doctrine, one can obtain examples and descriptions that help clarify its meaning. However, in some of the examples of international instruments such as flogging, kicking, throwing, burning, slapping and corporal punishment and is against the law as a candidate listed.

5) the terms of corporal punishment of children in the Shiite jurisprudence is, as usual with the terms "discipline" and "punishment" is expressed. "Discipline" means the person to invite to good and evil vices and detained, and sometimes mean by punishment, punishment and listen financial loss can be achieved and also a kind of punishment is retribution and punishment to do for their offenses and sins that God has not determined the amount and size, can be applied.

6) What the traditions and opinions about corporal punishment Shiite jurists stated, the term "discipline Sabee" states. And the concept of "discipline" is that human children are invited to the good and forbid the evil and impurity. Noting and review the words and arguments against Shiite jurisprudence on this issue because some people believe that the Shiite jurisprudence: Rulers, parents and teachers can discipline their children in order to train them, which is one of the examples of corporal punishment Are. Hence Jurisprudence corporal punishment as an act in the interests of expediency and to prevent children from doing their excellent behavior and good deeds of their obscene and Guidance, is permitted.

7) physical Tbyh Islam is not the first educational method, to be used in all situations, but can be considered as a way of secondary education and as a last resort and modify children's behavior, and the goal of punishment, education and child behavior modification and application of this method to be used this shall be such that amendments affecting the child's education or to stop operating, and if the desired result is not achieved should not be used because improper use may cause frustration and lack of confidence and pessimism child and opportunity for diversion and social problems such as crime, he will be provided in the future.

8) allows for corporal punishment of children that science as opposed to having it look ugly action and punishment. And steps must be followed and its degrees and not more than crime.

9) If the children to be punished, be warned or punishment for wrong behavior or illegal does not know, he should not be punished because the purpose of punishment and children's awareness and behavior modification was obtained when the purpose of punishment is meaningless .

\section{References}

Akbar, S. A. (1996). changes and behavioral therapy. Tehran: Dana.

Akbar, S. A. (2007). Psychology of Education. Tehran: Cognizant.

Ansari, the power of God. (2007). Reprimand. Qom: Islamic Sciences and Culture Academy.

Ayrvanyan, A. et al. (2011). Child abuse, Azlt of the response. Tehran: happy.

Believer Qomi, Mohammad. Bita. Tahrir principles. Unwarranted.

Ebadi, S. (2007). Rights of the Child (4th ed.). Tehran: the hotspot.

Excellent, J. (2006). internal armed conflicts international humanitarian law. Tehran: Publication of.

Ghaemi Moghaddam, M. R. (2004). unhealthy behaviors in terms of Islamic education. Qom: Institute of Science.

Ghasem Zadeh, S. M. (2002). civil rights of persons and Mhjvryn (6th ed.). Tehran: Publication side.

Grace, A. R. (1992). General conjunction implementation of Islamic criminal law. Dvm.thran Printing: Printing and Publishing Ministry of Culture and Islamic Guidance.

Hassan, I. S. (2008). Civil Rights (Vol 5, 15th ed.). Tehran: Islamiyah.

Hosseini Nejad, H. A. (1992). civil liability (1st ed.). Tehran: Tehran University Academic Center.

Jafari, M., \& Langroud, J. (1998). Rights terminology (8th ed.). Tehran: Treasure knowledge.

Kant, I. (2004). Virtuous. Translation of Sanei Darreh Bidi. Tehran: The role and image.

Katouzian, N. (1993). Landmark legislation. Tehran: Publication of Yalda.

Knowledge, M. H. (2000). puberty. Critique magazine, (12). 
Qutb, M. (2010). Islamic educational methods and their practical implementation. TEA: Mahmoud Ibrahim. Sanandaj: Aras.

\section{Copyrights}

Copyright for this article is retained by the author(s), with first publication rights granted to the journal.

This is an open-access article distributed under the terms and conditions of the Creative Commons Attribution license (http://creativecommons.org/licenses/by/3.0/). 